\title{
Co-occurrence and transfer of fixed nitrogen from Trichodesmium spp. to diatoms in the low-latitude Kuroshio Current in the NW Pacific
}

\author{
Yuh-ling Lee Chen ${ }^{1,2, *}$, Sing-how Tuo ${ }^{1}$, Houng-Yung Chen ${ }^{2,3}$ \\ ${ }^{1}$ Department of Marine Biotechnology and Resources, ${ }^{2}$ Asia-Pacific Ocean Research Center, and ${ }^{3}$ Institute of Marine Biology, \\ National Sun Yat-sen University, Kaohsiung 80424, Taiwan, ROC
}

\begin{abstract}
Actively growing Trichodesmium spp. are known to release their newly fixed nitrogen (N) into the surrounding N-limited water. Although newly released fixed N could potentially enhance the growth of nearby non-diazotrophic phytoplankton, the interactions of Trichodesmium spp. and other co-occurring cells, i.e. diatoms, have never been well documented. We conducted laboratory ${ }^{15} \mathrm{~N}$ tracer experiments to investigate the trophic interactions of $T$. erythraeum and diatoms in culture. Field studies were carried out to examine spatial-temporal distributions of Trichodesmium spp. and diatoms in the low-latitude Kuroshio Current and the neighboring northern South China Sea (SCS). Enrichment of ${ }^{15} \mathrm{~N}$ occurred in 3 species of cultured diatoms when they were incubated with T. erythraeum IMS101 in culture media enriched with gaseous ${ }^{15} \mathrm{~N}_{2}$, which confirmed the transfer of newly fixed $\mathrm{N}$ from $T$. erythraeum to diatoms. Field results showed that in the Kuroshio, where Trichodesmium spp. flourished in the warm seasons, the abundances of Trichodesmium spp. and diatom cells with $>10 \mu \mathrm{m}$ diameter were positively correlated $(\mathrm{p}<0.05)$. During the warm seasons, diatom vertical distributions showed a surface-abundance maximum that coincided with the depth of highest cell densities of Trichodesmium spp. and a second abundance maximum near the nitracline. The diatom surface-abundance maximum disappeared in the cold seasons, when the Trichodesmium spp. population languished. The bimodal distribution of diatoms and the co-occurrence of diatom and Trichodesmium spp. abundance maxima recurred as Trichodesmium spp. abundance increased when the warm seasons returned. In contrast to the Kuroshio, the SCS, inhabited sparsely by Trichodesmium spp., showed no surface abundance maxima in the vertical distributions of Trichodesmium spp. or diatoms. Both field and laboratory data suggest that the co-occurrence of Trichodesmium spp. and diatoms might be driven by the transfer of $\mathrm{N}$ fixed by Trichodesmium spp. to diatoms in the N-limited oligotrophic ocean. Because diatoms are more effective than Trichodesmium spp. in exporting $\mathrm{N}$ and carbon to depth, the $\mathrm{N}$ exudation by Trichodesmium spp. that supports diatom growth could represent an important pathway of $\mathrm{N}$ and carbon export to depth in tropical and subtropical oceans.
\end{abstract}

KEY WORDS: Trichodesmium spp. $\cdot$ Diatoms $\cdot$ Kuroshio $\cdot$ South China Sea $\cdot \mathrm{N}_{2}$ fixation Resale or republication not permitted without written consent of the publisher

\section{INTRODUCTION}

Cyanobacteria of the genus Trichodesmium are often considered to be the most important dinitrogen $\left(\mathrm{N}_{2}\right)$-fixing diazotrophs in tropical and subtropical seas (Capone et al. 1997). Recently, unicellular cyanobacteria also have been recognized as important diazotrophs in the nitrogen $(\mathrm{N})$ cycle (Montoya et al.
2004). Trichodesmium spp. often prospers in stratified open oceans where turbulence and input of the nitrate advected from deep waters are low and the supply of iron (Fe) or phosphorus (P) is sufficient (Capone 2001). When $\mathrm{N}$ is limiting, $\mathrm{N}_{2}$ fixation by Trichodesmium spp. plays a significant role in the $\mathrm{N}$ cycle. Up to half of the new production in the subtropical North Pacific Ocean (Karl et al. 1997) and more than two-thirds in the North 
Atlantic Ocean (Carpenter \& Romans 1991) is attributed to $\mathrm{N}_{2}$ fixation by Trichodesmium spp. Despite the trophic significance, little is known about the fate of $\mathrm{N}$ and associated carbon (C) from $\mathrm{N}_{2}$ fixation exported from the euphotic zone. The effects of Trichodesmium spp. blooms are thought to be limited mainly to the upper water column because of their positive cell buoyancy (Walsby 1992). Loss of trichomes due to sinking appears to be minor compared with exudation of dissolved N products, lyses of decaying cells, and grazing by zooplankton (Mulholland 2007). Thus, dissolved $\mathrm{N}$ species produced by Trichodesmium spp. are believed to recycle primarily in the ocean surface waters.

Actively growing Trichodesmium spp. can release up to $50 \%$ of newly fixed $\mathrm{N}$ into the surrounding waters as dissolved organic N (DON) (Glibert \& Bronk 1994), amino acids (Capone et al. 1994), or ammonium $\left(\mathrm{NH}_{4}{ }^{+}\right.$) (Mulholland \& Capone 2001, Mulholland et al. 2004). Accumulation of $\mathrm{NH}_{4}^{+}$and/or DON in and around Trichodesmium spp. blooms was observed in the Pacific (Devassy et al. 1978, Karl et al. 1992, 1997) and the Gulf of Mexico (Lenes et al. 2001), and in aging Trichodesmium spp. cultures (Mulholland \& Capone 2001); however, it is not known if other phytoplankton benefit from the release of $\mathrm{N}$ from Trichodesmium spp. during its blooms. In N-deficient environments, competition for $\mathrm{N}$ uptake among the non-diazotrophic phytoplankton is expected. Field observations that demonstrate such trophic linkages between the extracellular products of the diazotrophs and the uptake by nearby planktonic organisms have been rare even though diazotroph blooms are common (Capone et al. 1997). In the Gulf of Mexico, N released from Trichodesmium spp. blooms supported a moderate bloom of the toxic dinoflagellate Karenia brevis (Mulholland et al. 2006). Curiously, distribution of diatoms was not linked to this Trichodesmium spp. bloom. In oligotrophic oceans where N is limiting, Synechococcus spp. and Prochlorococcus spp. are the common dominant phytoplankton; with cell sizes $<2 \mu \mathrm{m}$, their contributions to $\mathrm{C}$ and $\mathrm{N}$ export to depth through direct sinking are small. In contrast, phytoplankton with larger cell sizes, such as diatoms, tend to sink and contribute more significantly to sinking fluxes. The sinking rates of phytoplankton are closely related to their cell sizes (Takahashi \& Bienfang 1983). While <3 $\mu \mathrm{m}$ sized phytoplankton did not sink, those of size 3 to $20 \mu \mathrm{m}$ sank at a rate of $0.09 \mathrm{~m} \mathrm{~d}^{-1}$, and those $>20 \mu \mathrm{m}$ sank at $0.29 \mathrm{~m} \mathrm{~d}^{-1}$. If the $\mathrm{N}$ exuded from Trichodesmium spp. blooms could enhance the population of nearby diatoms, it would potentially lead to greater $\mathrm{C}$ export to depth.

The upstream Kuroshio Current between Taiwan and the Philippines has high abundance of Tricho- desmium spp. in summer and low abundance in winter (Chen et al. 2008). With its origin in the tropical ocean, the Kuroshio is characterized by high surface temperatures, low surface nutrients (especially N), and a deep nitracline, conditions that support thriving populations of Trichodesmium spp. In summer when Trichodesmium spp. flourishes in the Kuroshio, it is sparse in the neighboring northern South China Sea (SCS), where surface water was similarly warm and limiting in N (Chen et al. 2003). Unlike in the Kuroshio, the Trichodesmium spp. population in the SCS varies little among seasons.

Our observations of the distribution of diazotrophic phytoplankton in the Kuroshio in 2006 and 2007 indicated that diatoms flourished in summer in surface water in which nutrient conditions seemed unfavorable to support phytoplankton growth. Trichodesmium spp. also were abundant in the diatom-rich surface water. We postulated that the general increase in diatoms was a response to increased abundance of Trichodesmium spp. The present research was undertaken to determine if diatoms benefit from the flourishing of Trichodesmium spp. In laboratory tracer experiments, diatoms were incubated with $T$. erythraeum to determine whether $\mathrm{N}_{2}$ fixation products from $T$. erythraeum could be transferred and detected in diatoms. Possible associations of Trichodesmium spp. and diatom biomass distributions also were studied in the upstream Kuroshio and in the northern SCS. The seasonal and regional contrasts in Trichodesmium spp. biomass between the Kuroshio and SCS offered an excellent opportunity to study the associations. The results of the laboratory experiments helped to explain that the association was related to nutrient interactions between Trichodesmium spp. and diatoms.

\section{MATERIALS AND METHODS}

Study strategy. The present study included 2 parts: (1) laboratory tracer experiments to examine the transfer of newly fixed $\mathrm{N}$ by Trichodesmium erythraeum to diatoms and other small non-diazotrophs; (2) field investigations to examine the cell abundances of Trichodesmium spp. and diatoms in natural waters.

Laboratory experiments. Four diatom species Thalassiosira weissflogii (CCMP 1587), Ditylum brightwellii (CCMP 358), Chaetoceros affinis (CCMP 158), and C. pelagicus (CCMP 195), and 2 non-diazotrophic picophytoplankton species, Prochlorococcus marinus (CCMP 2773) and Synechococcus sp. (CCMP 1768), were each incubated with or without Trichodesmium erythraeum IMS101. All test phytoplankton except $C$. pelagicus were studied in Expt A, and C. pelagicus, Thalassiosira weissflogii, and Synechococcus sp. were 
studied in Expt B. Stock cultures and all experiments were kept in the same incubator at $26^{\circ} \mathrm{C}$ with an alternating light regime of $12 \mathrm{~h}$ light:12 h dark. ${ }^{15} \mathrm{~N}_{2}$ gas was provided as the source for $\mathrm{N}_{2}$ fixation (Montoya et al. 1996), thus allowing us to follow the possible trophic transfer after $\mathrm{N}_{2}$ fixation activity. Enrichment of ${ }^{15} \mathrm{~N}$, indicated by a higher atomic percent (atom \%) of ${ }^{15} \mathrm{~N}$ in test diatom cells from the bottles with Trichodesmium erythraeum than those without, would show us that the newly fixed $\mathrm{N}$ from Trichodesmium erythraeum was taken up by the test phytoplankton. Trichodesmium erythraeum stock cultures were grown in YBC II medium that contained no fixed $\mathrm{N}_{\text {; }}$ monocultures of diatoms were grown in f/2 medium; Synechococcus sp. was grown in $\mathrm{f} / 2$ medium without silicate; and $P$. marinus was grown in YBC II medium plus $0.8 \mathrm{mM} \mathrm{NH}_{4} \mathrm{Cl}$. In order to acclimate the test cells to low $\mathrm{N}$ conditions, diatom cultures were concentrated by centrifugation and transferred to YBC II medium that contained $0.106 \mathrm{mM}$ of $\mathrm{Si}$, whereas Synechococcus sp. and P. marinus were transferred to YBC II medium $2 \mathrm{~d}$ before the incubation experiments were conducted.

Incubation experiments were conducted in four 1.211 polycarbonate (PC) bottles filled with YBC II medium plus Si to the final concentration equal to that of f/2 medium. Trichodesmium erythraeum filaments from stock culture were filtered on $3 \mu \mathrm{m}$ PC membranes and transferred to 2 of the 4 bottles as the treatment group. Two remaining bottles without Trichodesmium erythraeum were treated as the control group. An aliquot of the test phytoplankton in YBC II medium was inoculated into a $12 \mathrm{~cm}$ tubular cellulose membrane that had a volume capacity of $3.7 \mathrm{ml} \mathrm{cm}^{-1}$ (MWCO 50K, Cellu Sep H1, Membrane Filtration Products). The cellulose membrane allowed exchange of water and nutrients, but not phytoplankton cells, into and out of the tube. In Expt A, membrane tubes each containing 1 of the 5 test phytoplankton species (see Table 2) were placed simultaneously in each of the 4 incubation bottles; in Expt B, each tube had Chaetoceros pelagicus, Thalassiosira weissflogii, and Synechococcus sp. Before incubation, $\mathrm{NaH}^{13} \mathrm{CO}_{3}$ (99 atom \%, Isotec, SigmaAldrich) solution was added to the bottles to a final concentration of about $0.2 \mathrm{mmol}^{-1}$ to determine if phytoplankton cells were actively assimilating $\mathrm{C}$. The over-filled bottle was sealed with a Teflon-backed butyl septum cap and then $6 \mathrm{ml}$ of highly enriched ${ }^{15} \mathrm{~N}_{2}$ gas (99 atom \% ${ }^{15} \mathrm{~N}$, Isotec) was injected using a gas-tight syringe. The incubation experiments lasted for $24 \mathrm{~h}$. Once every 30 min during the light hours, each bottle was gently turned 10 times manually to facilitate water and nutrient mixing and exchange. Incuba- tion was stopped by removing and placing the tube in new YBC II medium. The tube was sonicated for $1 \mathrm{~min}$ to clean the outer surface. The test phytoplankton was removed from the tube by a pipette and vacuumfiltered gently onto a precombusted $\left(450^{\circ} \mathrm{C}, 4 \mathrm{~h}\right)$ Whatman GF/F filter paper. Trichodesmium erythraeum in the incubation bottle was filtered similarly. The filtered samples were fumed for $2 \mathrm{~h}$ with $\mathrm{HCl}$ to remove carbonate and were dried completely in a vacuum desiccator. The isotopic ratios ${ }^{13} \mathrm{C}:{ }^{12} \mathrm{C}$ and ${ }^{15} \mathrm{~N}:{ }^{14} \mathrm{~N}$ were measured with an ANCA-MASS 20-20 mass spectrometer (Europa Scientific). Measurements of ${ }^{13} \mathrm{C}$ atom \% and ${ }^{15} \mathrm{~N}$ atom $\%$ were reproducible at a precision of \pm 0.0002 and $\pm 0.0003 \%$, respectively.

Field investigations. Sampling: The water samples used to study Trichodesmium spp. and diatom abundances were collected from Stns K1, K2, and K3 in the upstream Kuroshio Current (Fig. 1) between October 2004 and May 2009 (Table 1). In addition to the 4 calendar seasons, sampling times were categorized by surface temperature: $>27.5^{\circ} \mathrm{C}$ as the warm-water season and $<26.3^{\circ} \mathrm{C}$ as the cool-water season. We used the samples collected between May 2004 and January 2007 (Table 1) at Stn S, the South East Asia Time Series

Table 1. Sampling stations and cruise dates in the Kuroshio Current and South China Sea (SCS). Stn S was the South East Asia Time Series Station (SEATS). Calendar seasons were categorized by sea surface temperature (SST): $>27.5^{\circ} \mathrm{C}$ as warm (W) and $<26.3^{\circ} \mathrm{C}$ as cool (C) water season

\begin{tabular}{|c|c|c|c|c|}
\hline Stn & Cruise & Dates & $\begin{array}{l}\text { SST } \\
\left({ }^{\circ} \mathrm{C}\right)\end{array}$ & Season \\
\hline \multicolumn{5}{|c|}{ Kuroshio Current } \\
\hline K1 & $1160^{\mathrm{a}}$ & 21-27 Jun 2006 & 29.0 & Summer (W) \\
\hline K2 & 1234 & $7-10 \mathrm{Jul} 2007$ & 30.2 & Summer (W) \\
\hline K2 & 1310 & 2-9 Aug 2008 & 29.5 & Summer (W) \\
\hline K3 & $1316^{\mathrm{a}}$ & 5-10 Sep 2008 & 29.3 & Summer (W) \\
\hline K1 & $734^{a, b}$ & $12-23$ Oct 2004 & 26.3 & Autumn (C) \\
\hline K1 & 1188 & 6-9 Nov 2006 & 27.5 & Autumn (W) \\
\hline K1 & $819^{a}$ & 18-30 Dec 2006 & 24.2 & Winter (C) \\
\hline K2 & $852^{\mathrm{a}}$ & $10-15$ Dec 2007 & 26.1 & Winter (C) \\
\hline K1 & SKII $^{\mathrm{a}}$ & 22 Apr-2 May 2005 & 27.5 & Spring (W) \\
\hline K2 & 1217 & 21-25 Apr 2007 & 27.7 & Spring (W) \\
\hline K2 & 899 & 17-20 May 2009 & 28.2 & Spring (W) \\
\hline \multicolumn{5}{|c|}{ SCS } \\
\hline $\mathrm{S}$ & 722 & 24 Jun-6 Jul 2004 & 30.0 & Summer (W) \\
\hline $\mathrm{S}$ & SC37 & 30 Jun-5 Jul 2006 & 29.6 & Summer (W) \\
\hline $\mathrm{S}$ & 812 & $18-24$ Oct 2006 & 27.8 & Autumn (W) \\
\hline $\mathrm{S}$ & 773 & $7-15$ Nov 2005 & 28.1 & Autumn (W) \\
\hline $\mathrm{S}$ & 780 & 23-30 Dec 2005 & 24.5 & Winter (C) \\
\hline $\mathrm{S}$ & 821 & 12-19 Jan 2007 & 24.1 & Winter (C) \\
\hline $\mathrm{S}$ & SC33 & 28 Mar-2 Apr 2005 & 25.4 & Spring $(\mathrm{C})$ \\
\hline $\mathrm{S}$ & $717^{\mathrm{a}}$ & 3-8 May 2004 & 27.9 & Spring (W) \\
\hline \multicolumn{5}{|c|}{$\begin{array}{l}{ }^{\text {a }} \text { The } \mathrm{N}_{2} \text { fixation rate for Trichodesmium colonies was measured } \\
\text { using the }{ }^{15} \mathrm{~N}_{2} \text { method } \\
{ }^{b} \text { A typhoon passed by }\end{array}$} \\
\hline
\end{tabular}




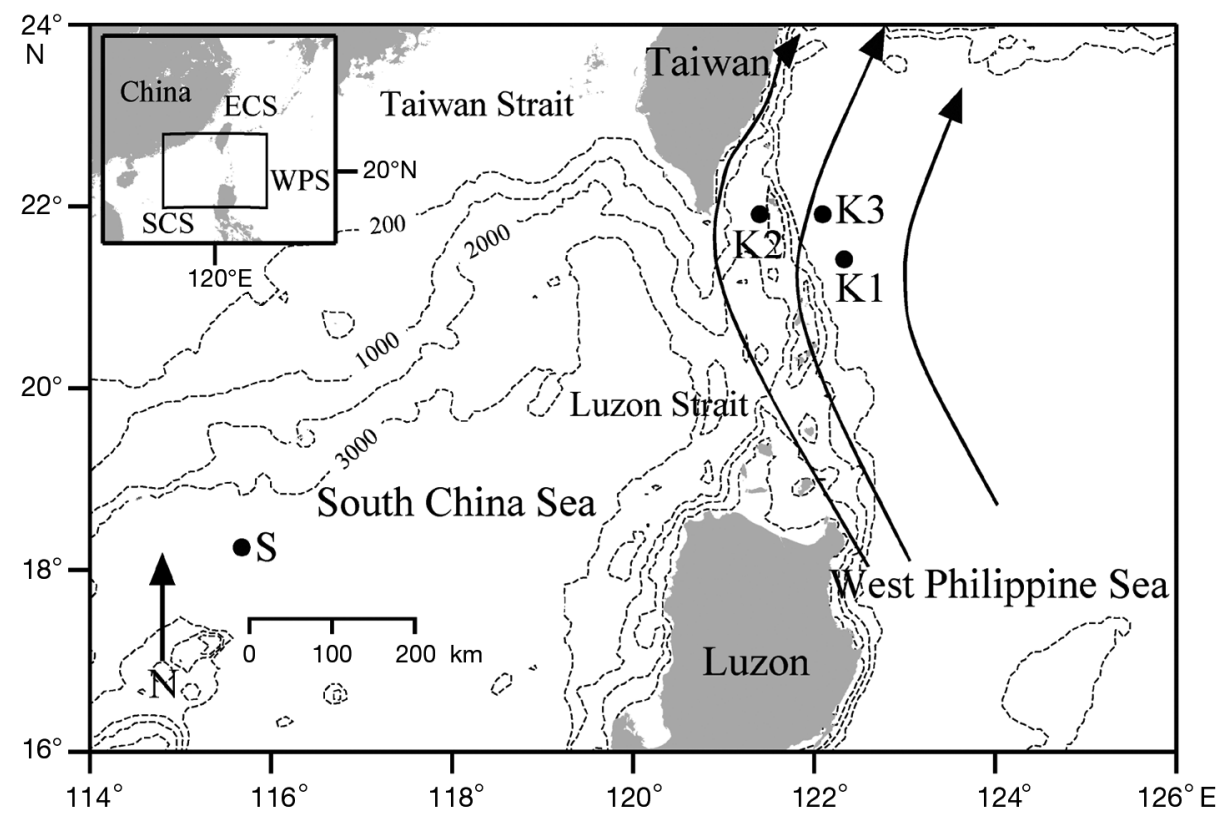

Fig. 1. Sampling stations on the upstream Kuroshio Current (Stns K1, K2, and K3) and the South China Sea (SCS) (Stn S). The path of the Kuroshio Current is indicated (arrows) (after Liang et al. 2003). ECS: East China Sea; WPS: West Philippine Sea

Station (SEATS) (Fig. 1), to represent the observations in the South China Sea (SCS). Some of the data sets on Trichodesmium spp. used in the present analysis have been published previously, including those for Stn K1 of Cruise 819 (Chen et al. 2008) and Cruise SKII (Chen et al. 2007, 2008), and for Stn S of Cruises 717, 722, 773, 780, SC33, SC37, 812, and 821 (Chen et al. 2008).

Collection of metadata: CTD (Seabird SBE-9) data, photosynthetically available radiation (PAR) readings (OSP200L, Biospherical), and water samples were obtained at all stations. The water samples were collected using 201 Go-Flo bottles from 6 depths corresponding to $100,46,38,13,6$, and $0.8 \%$ of surface irradiance. Aliquots of the sample water were used to determine concentrations of nutrients and for phytoplankton enumerations. Nitrate and nitrite $(\mathrm{N}+\mathrm{N})$ concentrations were determined first by the pink azo dye method adapted to a flow injection analyzer (Pai \& Riley 1994), which has a detection limit of $0.1 \mu \mathrm{M}$. When the $\mathrm{N}+\mathrm{N}$ concentrations were $<0.2 \mu \mathrm{M}$, the chemiluminescent method (Garside 1982) was used to measure nanomolar concentrations. Soluble reactive phosphorus (SRP) concentrations were measured by the molybdenum blue method, which has a detection limit of $0.2 \mu \mathrm{M}$, and silicate concentrations were measured by the silicomolybdenum blue method (Pai et al. 1990). If the SRP concentrations were $<0.4 \mu \mathrm{M}$, nanomolar concentrations were measured by the modified MAGIC method (Thomson-Bulldis \& Karl 1998).
The euphotic depth $\left(\mathrm{D}_{\text {eu }}\right)$ was defined as the depth at which light intensity was $0.8 \%$ of surface irradiance. The nitracline depth $\left(\mathrm{D}_{\mathrm{ni}}\right)$ was defined as the depth at which $\mathrm{N}+\mathrm{N}$ concentration equals $0.1 \mu \mathrm{M}$ (Le Borgne et al. 2002) and was used as an index to infer the nitrate availability to phytoplankton in the upper water column. Its value represents the stock abundance of surface nitrate as well as the upward diffusion potential of deep nitrate.

Enumeration of phytoplankton: Samples for phytoplankton enumeration were prepared on board by filtering 1.2 or $2.4 \mathrm{l}$ of seawater onto a $10 \mu \mathrm{m}$ Nuclepore filter ( $25 \mathrm{~mm}$ diameter). The filter paper was mounted on a microscope slide with immersion oil and a cover slip and kept in darkness at $-20^{\circ} \mathrm{C}$ until microscopic examination. Diatoms that passed through the $10 \mu \mathrm{m}$ filter were not examined. During microscopic examination, trichomes of Trichodesmium spp. on a slide were counted first on the entire filter at a magnification of 100 to $400 \times$ with blue excitation using a Zeiss epifluorescence microscope. The same slide then was reexamined for diatoms on one-half of the filter or at least 400 cells filter ${ }^{-1}$ at $400 \times$ magnification with phase contrast optics on a Zeiss Axiovert 35 inverted microscope. The diatoms were distinguished to genus, mainly according to Cupp (1977). The cell abundances of diatoms were the numbers of all genera together. Depth-integrated phytoplankton abundances were calculated by trapezoidal integration for the entire 
euphotic layer and expressed as trichomes $\mathrm{m}^{-2}$ or cells $\mathrm{m}^{-2}$. Depth-averaged phytoplankton abundances were calculated by dividing by euphotic depth and expressed as trichomes $\mathrm{m}^{-3}$ or cells $\mathrm{m}^{-3}$.

Measurement of Trichodesmium spp. $\mathbf{N}_{2}$ fixation rate in the field: In order to verify that Trichodesmium spp. were actively fixing $\mathrm{N}_{2}$, the ${ }^{15} \mathrm{~N}_{2}$ (g) assimilation rate of Trichodesmium spp. colonies was measured following Montoya et al. (1996). The measurements were made mostly in the Kuroshio but only once in the SCS (Table 1) because Trichodesmium spp. there were usually sparsely distributed and mostly in the form of single trichomes. Difficulty in collecting enough colonies often hampered the incubation experiments. To collect Trichodesmium spp. colonies, plankton nets of $100 \mu \mathrm{m}$ mesh were towed at low speed at 3 to $5 \mathrm{~m}$ depth. Trichodesmium spp. colonies were picked from collected plankton samples, placed in GF/F filtered seawater using plastic bacteriological transfer loops, and rinsed with filtered seawater. Ten to 40 colonies were placed in each $120 \mathrm{ml}$ glass bottle and then capped with a screw cap seal with rubber septa. Two hundred $\mu$ l of 99 atom $\%{ }^{15} \mathrm{~N}_{2}$ gas (Isotec) were injected into each bottle using a gas-tight syringe. The bottles were incubated for 3 to $5 \mathrm{~h}$ on deck under natural light in clear plastic incubators circulated with flow-through surface seawater. Incubations were terminated by filtering samples onto pre-combusted $\left(450^{\circ} \mathrm{C}, 4 \mathrm{~h}\right) \mathrm{GF} / \mathrm{F}$ filters. The filters were then frozen and stored at $-20^{\circ} \mathrm{C}$ until analysis. The $\mathrm{N}$ isotopes were quantified using an ANCA-MASS 20-20 mass spectrometer.

Statistical analysis. Mean ${ }^{15} \mathrm{~N}$ and ${ }^{13} \mathrm{C}$ signatures of the test phytoplankton were compared between the treatment (with Trichodesmium erythraeum) and control (without T. erythraeum) groups with $t$-tests. Seasonal differences of means of surface $\mathrm{N}+\mathrm{N}$ and SRP were tested using 1-way ANOVA. Stepwise multiple regression analysis (Draper \& Smith 1981) was used to examine the spatial and temporal relationships among averaged Trichodesmium spp. abundances in the euphotic zone, averaged diatom abundances in the euphotic zone, water temperature, and $\mathrm{D}_{\mathrm{ni}}$. Abundances of phytoplankton were all log-transformed for linearity. StatView programs (SAS Institute) were used to conduct the statistical procedures.

\section{RESULTS}

\section{Uptake of fixed $\mathbf{N}$ by test phytoplankton incubated with Trichodesmium erythraeum}

The incubation experiments showed that the diatoms and picophytoplankton took up newly fixed $\mathrm{N}$ released by Trichodesmium erythraeum (Table 2). After the $24 \mathrm{~h}$ incubation, 3 of the 4 test diatom species cultured with $T$. erythraeum showed significantly higher ${ }^{15} \mathrm{~N}$ signatures $(\mathrm{p}<0.05)$ than the controls. The fourth diatom, Chaetoceros pelagicus, showed higher ${ }^{15} \mathrm{~N}$ values (Table 2$)$ for the treatment group $(0.4283 \%)$ than the control $(0.3715 \%)$; however, the difference was not significant because of large within-treatment variations. The ${ }^{15} \mathrm{~N}$ uptakes of non-diazotrophic phytoplankton were not compared directly among species in the present study because the culture conditions, including temperature and illumination, were optimized for the growth of T. erythraeum, not necessarily for the co-incubating phytoplankton. The 2 picophytoplankton species tested also took up the fixed $\mathrm{N}$ released by $T$. erythraeum. The ${ }^{15} \mathrm{~N}$ value for Prochlorococcus marinus incubated with $T$. erythraeum was significantly $(\mathrm{p}<0.05)$ higher than the control

Table 2. Atom $\%{ }^{15} \mathrm{~N}$ and ${ }^{13} \mathrm{C}$ in 4 diatom species (Chaetoceros affinis, C. pelagicus, Ditylum brightwelli, and Thalassiosira weissflogii) and 2 non-diazotrophic picophytoplankton species (Synechococcus sp. and Prochlorococcus marinus) incubated with (treatment) and without (control) Trichodesmium erythraeum. Mean values $\pm \mathrm{SE} .{ }^{*} \mathrm{p}<0.05,{ }^{* *} \mathrm{p}<0.01$, na: not applicable

\begin{tabular}{|c|c|c|c|c|c|}
\hline \multirow{2}{*}{ Species } & \multicolumn{3}{|c|}{-Atom $\%{ }^{15} \mathrm{~N}$} & \multicolumn{2}{|c|}{ Atom $\%{ }^{13} \mathrm{C}-$} \\
\hline & Treatment & Control & $t$-test & Treatment & Control \\
\hline \multicolumn{6}{|l|}{ Expt A } \\
\hline Trichodesmium erythraeum & $3.0187 \pm 0.0095$ & na & na & $1.8948 \pm 0.0581$ & na \\
\hline C. affinis & $0.3924 \pm 0.0037$ & $0.3758 \pm 0.0011$ & $4.37^{*}$ & $1.6972 \pm 0.0254$ & $1.7700 \pm 0.0068$ \\
\hline D. brightwellii & $0.3832 \pm 0.0025$ & $0.3722 \pm 0.0001$ & $4.40^{*}$ & $1.6742 \pm 0.1600$ & $1.6458 \pm 0.0246$ \\
\hline Thalassiosira weissflogii & $0.3789 \pm 0.0006$ & $0.3716 \pm 0.0001$ & $12.00^{* *}$ & $2.9592 \pm 0.0249$ & $3.0279 \pm 0.0423$ \\
\hline Synechococcus sp. & $0.3889 \pm 0.0044$ & $0.3777 \pm 0.0038$ & 1.93 & $1.1549 \pm 0.0100$ & $1.1617 \pm 0.0203$ \\
\hline P. marinus & $0.3848 \pm 0.0019$ & $0.3699 \pm 0.0004$ & $7.91^{* *}$ & $1.1850 \pm 0.0149$ & $1.1871 \pm 0.0214$ \\
\hline \multicolumn{6}{|l|}{ Expt B } \\
\hline Trichodesmium erythraeum & $1.2616 \pm 0.1545$ & na & na & $1.8945 \pm 0.0698$ & na \\
\hline C. pelagicus & $0.4283 \pm 0.0265$ & $0.3715 \pm 0.0010$ & 2.15 & $1.2428 \pm 0.0121$ & $1.2317 \pm 0.0676$ \\
\hline Thalassiosira weissflogii & $0.3969 \pm 0.0095$ & $0.3682 \pm 0.0006$ & $3.02^{*}$ & $1.5822 \pm 0.1865$ & $1.9061 \pm 0.0849$ \\
\hline Synechococcus sp. & $0.3863 \pm 0.0024$ & $0.3740 \pm 0.0035$ & $2.93^{*}$ & $1.4395 \pm 0.0218$ & $1.4567 \pm 0.0080$ \\
\hline
\end{tabular}




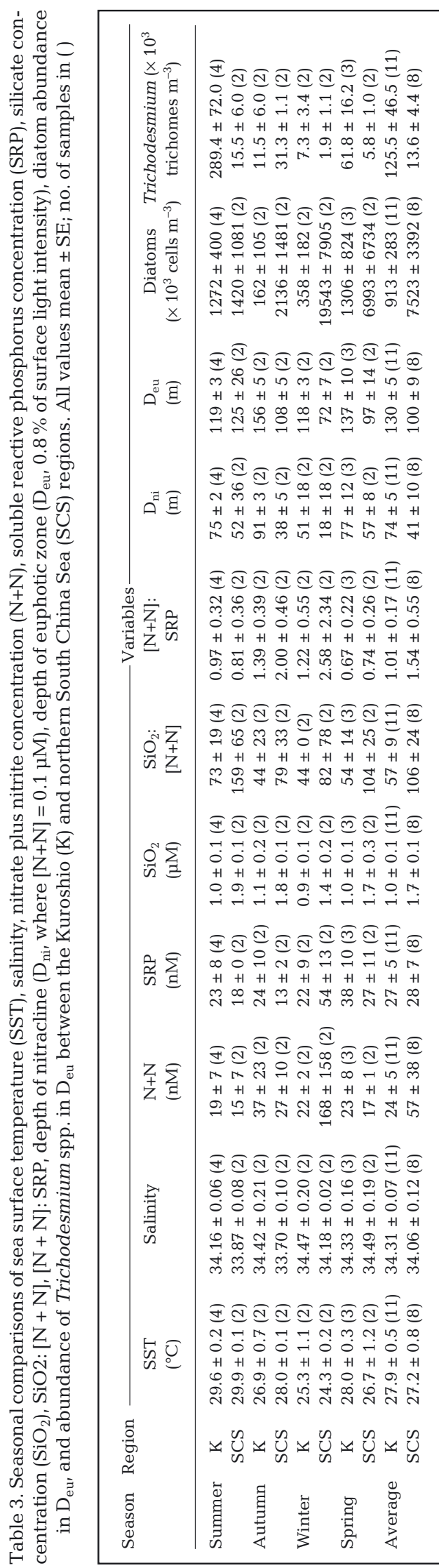

(Table 2). The ${ }^{15} \mathrm{~N}$ value for Synechococcus sp. incubated with $T$. erythraeum was significantly higher than the control in Expt B, but not in Expt A (Table 2). Chlorophyll concentrations of the Synechococcus sp. culture measured before Expt A indicated that the culture was not in the exponential growth phase.

$\mathrm{C}$ assimilation data, as revealed by the atom $\%{ }^{13} \mathrm{C}$ values (Table 2), suggested that all phytoplankton were growing during the incubation experiments, although whether each culture was at its maximum growth phase or all cultures were in a similar growing stage was not determined. The $\mathrm{C}$ assimilation rates did not differ significantly between the treatments and the controls for any test non-diazotrophic phytoplankton, although average ${ }^{13} \mathrm{C}$ values were lower for the treatments than the controls in 6 out of the 8 tests (Table 2).

\section{Water properties of the field samples}

Surface water in the upstream Kuroshio was generally more saline and more oligotrophic than in the northern SCS. While annual ranges in surface water temperature were comparable between the Kuroshio (25.3 to $29.6^{\circ} \mathrm{C}$ ) and $\mathrm{SCS}\left(24.3\right.$ to $\left.29.9^{\circ} \mathrm{C}\right)$, the annual range of salinity was generally higher in the Kuroshio (34.16 to 34.47 ) than in the SCS (33.70 to 34.49). The regional salinity difference was most obvious in summer (Table 3). Surface concentrations of nutrients essential for phytoplankton growth were generally lower and less varied seasonally in the Kuroshio than the SCS (Table 3). Mean surface N+N concentration was lower in the Kuroshio (24 nM) than in the SCS (57 nM). Mean $\mathrm{D}_{\text {ni }}$ was deeper in the Kuroshio (74 m) than the SCS (41 m). Wintertime N+N (168 nM) and SRP concentrations (54 nM) in the SCS were 10 times and 3 times the summertime values, respectively. By contrast, surface $\mathrm{N}+\mathrm{N}$ concentrations (19 to $37 \mathrm{nM}$ ) and SRP concentrations (23 to $38 \mathrm{nM}$ ) in the Kuroshio remained low all year and did not differ significantly seasonally ( $p>0.05$ ). Nevertheless, $D_{n i}$ was shallowest in winter in both regions; mean $D_{n i}$ in the Kuroshio was $51 \mathrm{~m}$ in winter and 74 to $91 \mathrm{~m}$ in other seasons, and in the SCS it was $18 \mathrm{~m}$ in winter and 38 to $57 \mathrm{~m}$ in other seasons (Table 3 ). This indicated that nitrate diffusion from deep water was more intense in winter than in other seasons even in the 2 tropicalsubtropical regions. The N+N:SRP ratios in both regions were $<2.6$ (Table 3 ), much lower than the Redfield ratio of 16 , which indicated potential $\mathrm{N}$ limitation. In contrast to the state of $\mathrm{N}$ deficiency, silicate in both regions was relatively abundant (Table 3). Surface silicate concentrations averaged $1.0 \mu \mathrm{M}$ in the Kuroshio, with little seasonal variation, 
and 1.4 to $1.9 \mu \mathrm{M}$ in the $\mathrm{SCS}$. The average $\mathrm{SiO}_{2}: \mathrm{N}+\mathrm{N}$ ratios of 57 in the Kuroshio and 106 in the SCS were much greater than the Si:N ratio of 1.12 described by Brzezinski (1985), and indicated silicate sufficiency. These results suggest that the growth of diatoms in both regions was more likely to be limited by $\mathrm{N}$ than by silica. The average $D_{\text {eu }}$ was $130 \mathrm{~m}$ in the Kuroshio and $100 \mathrm{~m}$ in the SCS.

\section{Diatom assemblages}

Major diatom genera in the surface Kuroshio changed little seasonally. Chaetoceros was the predominant genus throughout the year (Table 4), followed by Nitzschia, Bacteriastrum, and Pseudonitzschia, with varying degrees of seasonal dominance. In contrast, surface diatom assemblages in the SCS were more variable, with the major genera being Nitzschia and Chaetoceros in summer and autumn and Chaetoceros and Bacteriastrum in winter and spring. The genera Thalassionema, Rhizosolenia, Pseudonitzschia, and Dactyliosolen were also encountered frequently (Table 4).

Richelia spp.-diatom consortia or diazotrophic diatoms (D-D) are diatoms with endo- or ecto-symbiotic $\mathrm{N}_{2}$-fixing Richelia spp.-like cyanobacteria. They constituted between 1.0 and $4.4 \%$ of the total diatom cell counts in the Kuroshio and between $<0.01$ and $1.2 \%$ in the SCS (Table 5). They showed the same distribution patterns as Trichodesmium spp., being more abundant in the Kuroshio than in the SCS. In the Kuroshio, the mean water-column D-D densities in summer and spring were about twice those in winter and autumn. In the SCS, the mean water-column D-D densities in summer and autumn were $>5$ times those in winter and spring, showing an inverse trend to the abundance of total diatoms (Table 5). Although the abundances of Richelia spp. and Trichodesmium spp. in the Kuroshio

Table 4. Seasonal differences in major diatom genera in order of cell abundance in the Kuroshio Current and the South China Sea (SCS)

\begin{tabular}{|c|c|c|c|}
\hline Summer & Autumn & Winter & Spring \\
\hline \multicolumn{4}{|l|}{ Kuroshio } \\
\hline Chaetoceros & Chaetoceros & Chaetoceros & Chaetoceros \\
\hline Nitzschia & Pseudo-nitzschia & Bacteriastrum & Nitzschia \\
\hline Bacteriastrum & Nitzschia & Pseudo-nitzschia & Bacteriastrum \\
\hline Pseudo-nitzschia & Bacteriastrum & Nitzschia & Pseudo-nitzschia \\
\hline \multicolumn{4}{|l|}{ SCS } \\
\hline Nitzschia & Nitzschia & Chaetoceros & Chaetoceros \\
\hline Chaetoceros & Chaetoceros & Bacteriastrum & Bacteriastrum \\
\hline Pseudo-nitzschia & Thalassionema & Dactyliosolen & Nitzschia \\
\hline Thalassionema & Pseudo-nitzschia & Rhizosolenia & Pseudo-nitzschia \\
\hline
\end{tabular}

Table 5. Richelia spp. Seasonal and regional contrasts of water-column-integrated abundances of total diatoms $(\mathrm{T})$ and Richelia spp.-diatom consortia (R), and the relative importance (R/T) of R in the Kuroshio Current and the South China

Sea (SCS). Mean values \pm SE. n: number of stations

\begin{tabular}{|lccc|}
\hline $\begin{array}{l}\text { Seasons } \\
(\mathrm{n})\end{array}$ & $\begin{array}{c}\mathrm{T} \\
\left(\times 10^{6} \text { cells m}^{-2}\right)\end{array}$ & $\begin{array}{c}\mathrm{R} \\
\left(\times 10^{6} \text { cells m}^{-2}\right)\end{array}$ & $\begin{array}{c}\mathrm{R} / \mathrm{T} \\
(\%)\end{array}$ \\
\hline Kuroshio & & & \\
Summer (4) & $152.4 \pm 89.1$ & $2.9 \pm 1.4$ & $2.2 \pm 0.6$ \\
Autumn (2) & $24.8 \pm 15.6$ & $1.3 \pm 1.2$ & $3.8 \pm 2.4$ \\
Winter (2) & $41.8 \pm 20.5$ & $1.2 \pm 0.4$ & $4.4 \pm 3.0$ \\
Spring (3) & $163.5 \pm 134.7$ & $2.0 \pm 2.2$ & $1.0 \pm 0.4$ \\
SCS & & & \\
Summer (2) & $149.4 \pm 98.5$ & $0.7 \pm 0.4$ & $1.2 \pm 1.1$ \\
Autumn (2) & $223.0 \pm 150.0$ & $1.1 \pm 0.1$ & $0.9 \pm 0.6$ \\
Winter (2) & $1351.8 \pm 433.7$ & $0.1 \pm 0.0$ & $<0.01$ \\
Spring (2) & $583.9 \pm 557.1$ & $0.2 \pm 0.1$ & $0.2 \pm 0.1$ \\
& & & \\
\hline
\end{tabular}

were not significantly correlated $(\mathrm{r}=0.46, \mathrm{p}=0.15, \mathrm{n}=$ 11 ), in the SCS they were positively correlated. The linear regression equation depicting their relationship in the SCS $\left(\mathrm{r}^{2}=0.81, \mathrm{p}<0.01, \mathrm{n}=8\right)$ was: Richelia spp. density $\left(\times 10^{3}\right.$ filaments $\left.\mathrm{m}^{-3}\right)=1.759+0.35 \times$ Trichodesmium spp. density $\left(\times 10^{3}\right.$ trichomes $\left.\mathrm{m}^{-3}\right)$. D-D abundance was not subtracted from the total diatom abundance in the statistical analyses because its relative importance in the total diatom population was low in the present study.

\section{Abundances of diatoms and Trichodesmium spp. and related environmental factors}

Both diatoms and Trichodesmium spp. flourished during spring and summer in the Kuroshio (Table 3). The cell densities of diatoms in the euphotic layer of the Kuroshio were 3 to 8 times higher in spring and summer than in autumn and winter. The high variation of the springtime diatom density (1306 $\times 10^{3} \pm 824 \times 10^{3}$ cells $\mathrm{m}^{-3}$ ) was attributed to a high value of $2940 \times 10^{3}$ cells $\mathrm{m}^{-3}$ at Stn K2 during Cruise 899 in late spring (Table 1). The abundance of Trichodesmium spp. showed a similar seasonal pattern, with trichome density being 5 to 40 times higher in spring and summer than in autumn and winter (Table 3). There was a positive relationship between the abundances of diatoms and Trichodesmium spp. in the Kuroshio (Fig. 2A). The regression equation depicting this significant relationship in the Kuroshio is as follows: $\log$ Diatom density $\left(\times 10^{3}\right.$ cells 


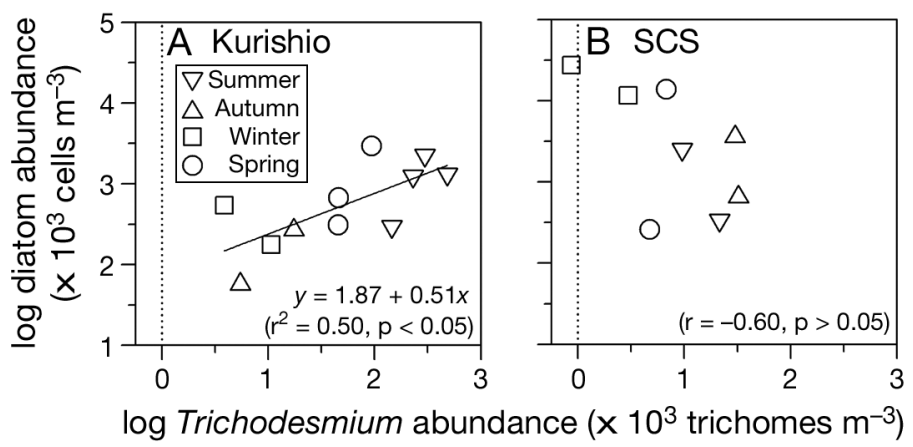

Fig. 2. Trichodesmium spp. Relationships between watercolumn-averaged cell abundances of diatoms and Trichodesmium spp. in (A) the Kuroshio and (B) the South China Sea (SCS)
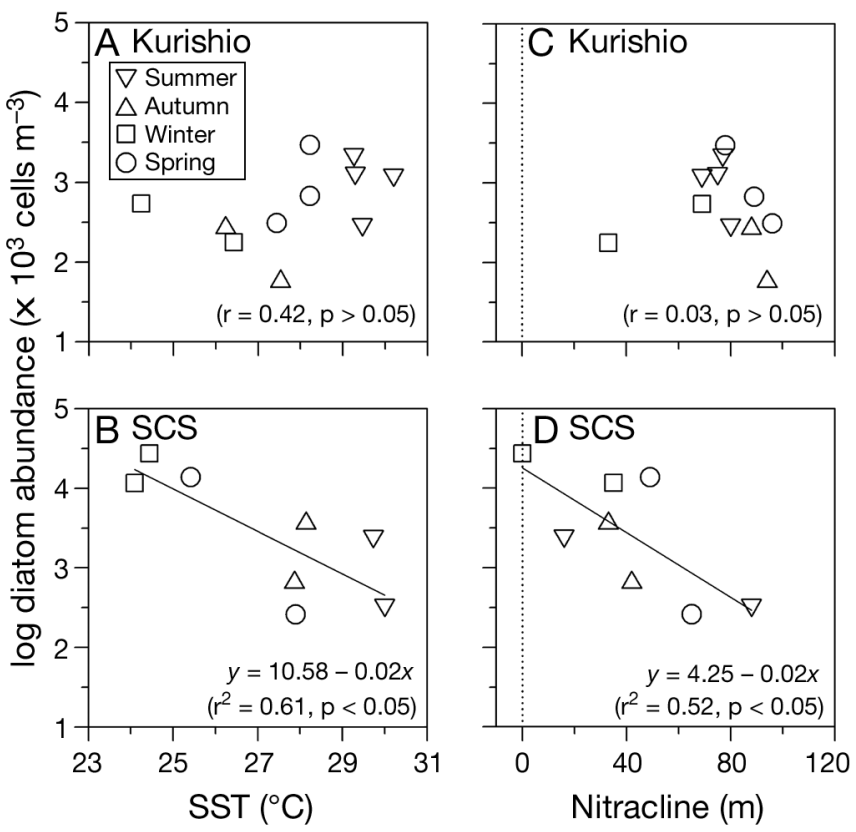

Fig. 3. Relationships between water-column-averaged cell abundance of diatoms and $(A, B)$ sea surface temperature (SST) and $(\mathrm{C}, \mathrm{D})$ nitracline in $(\mathrm{A}, \mathrm{C})$ the Kuroshio and $(\mathrm{B}, \mathrm{D})$ the South China Sea (SCS)

$\left.\mathrm{m}^{-3}\right)=1.87+0.51 \times \log$ Trichodesmium spp. density $(\times$ $10^{3}$ trichomes $\left.\mathrm{m}^{-3}\right)\left(\mathrm{r}^{2}=0.50, \mathrm{p}<0.05, \mathrm{n}=11\right)$.

The annual mean Trichodesmium spp. density in the SCS was one-ninth of that in the Kuroshio; however, the diatom density in the SCS was 8 times that in the Kuroshio (Table 3). Even during its greatest abundance, Trichodesmium spp. in the SCS was only 5 to $10 \%$ of the abundance in the Kuroshio (Table 3). The average cell density of diatoms in the SCS euphotic layer was highest in winter, which was 3, 9, and 14 times that of densities in spring, autumn, and summer, respectively. Unlike in the Kuroshio, the abundances of diatoms and Trichodesmium spp. in the SCS were not significantly correlated (Fig. 2B). The negative value of its correlation coefficient $(\mathrm{r}=$ $-0.60, p>0.05$ ) illustrated the opposite seasonal abundance patterns of the 2 phytoplankton taxa. Diatom abundance in the SCS was high when water temperature was low and/or the nitracline was shallow. The euphotic layer diatom abundance was related negatively to both surface water temperature (SST) and nitracline depth in the SCS (Fig. 3). The significant relationships for the SCS are depicted by 2 linear regression equations:

$\log$ Diatom density $\left(\times 10^{3}\right.$ cells $\left.\mathrm{m}^{-3}\right)=10.58-0.26 \times$ $\operatorname{SST}\left({ }^{\circ} \mathrm{C}\right)\left(\mathrm{r}^{2}=0.61, \mathrm{p}<0.05, \mathrm{n}=8\right)$;

and

$\log$ Diatom density $\left(\times 10^{3}\right.$ cells m $\left.\mathrm{m}^{-3}\right)=4.25-0.02 \times$

Nitracline depth $(\mathrm{m})\left(\mathrm{r}^{2}=0.52, \mathrm{p}<0.05, \mathrm{n}=8\right)$.

By contrast, the diatom abundance in the Kuroshio (Fig. 3A,C) was not related either to SST $(r=0.42, p>$ $0.05, \mathrm{n}=11)$ or to nitracline depth $(\mathrm{r}=0.03, \mathrm{p}>0.05$, $\mathrm{n}=11)$.

\section{Vertical distribution of diatoms and Trichodesmium spp.}

Vertical distributions of diatoms and Trichodesmium spp. differed seasonally between the 2 regions (Figs. 4 $\& 5)$. In the Kuroshio during the warm water season, vertical distribution of diatom abundance showed 2 maxima, 1 near the surface and 1 near the nitracline (Fig. 4). Trichodesmium spp. abundance, in contrast, had a single maximum near the surface. The Trichodesmium spp. maximum and the surface maximum of diatoms were at about the same depth. Both phytoplankters were distributed densely in the upper $20 \mathrm{~m}$ of the water column (Fig. 4A,D). While Trichodesmium spp. languished in the autumn, the diatom surface maximum dissipated, but the deeper diatom maximum remained near the nitracline (Fig. 4B). Diatoms were distributed above or around the nitracline (Fig. 4C) in the upper $60 \mathrm{~m}$ in winter when Trichodesmium spp. were scarce and the nitracline was shallow (Table 3). As the nitracline deepened in spring (Table 3), Trichodesmium spp. reappeared in the surface water. The bimodal distribution of diatoms reappeared and the surface maximum again aligned with the Trichodesmium spp. maximum (Fig. 4D). In contrast to the Kuroshio, the vertical distribution of diatoms in the SCS did not have a near-surface maximum even in summer and autumn, when Trichodesmium spp. was most abundant in that region (Fig. 5A,B). Diatoms generally were concentrated near the nitracline in the SCS. 


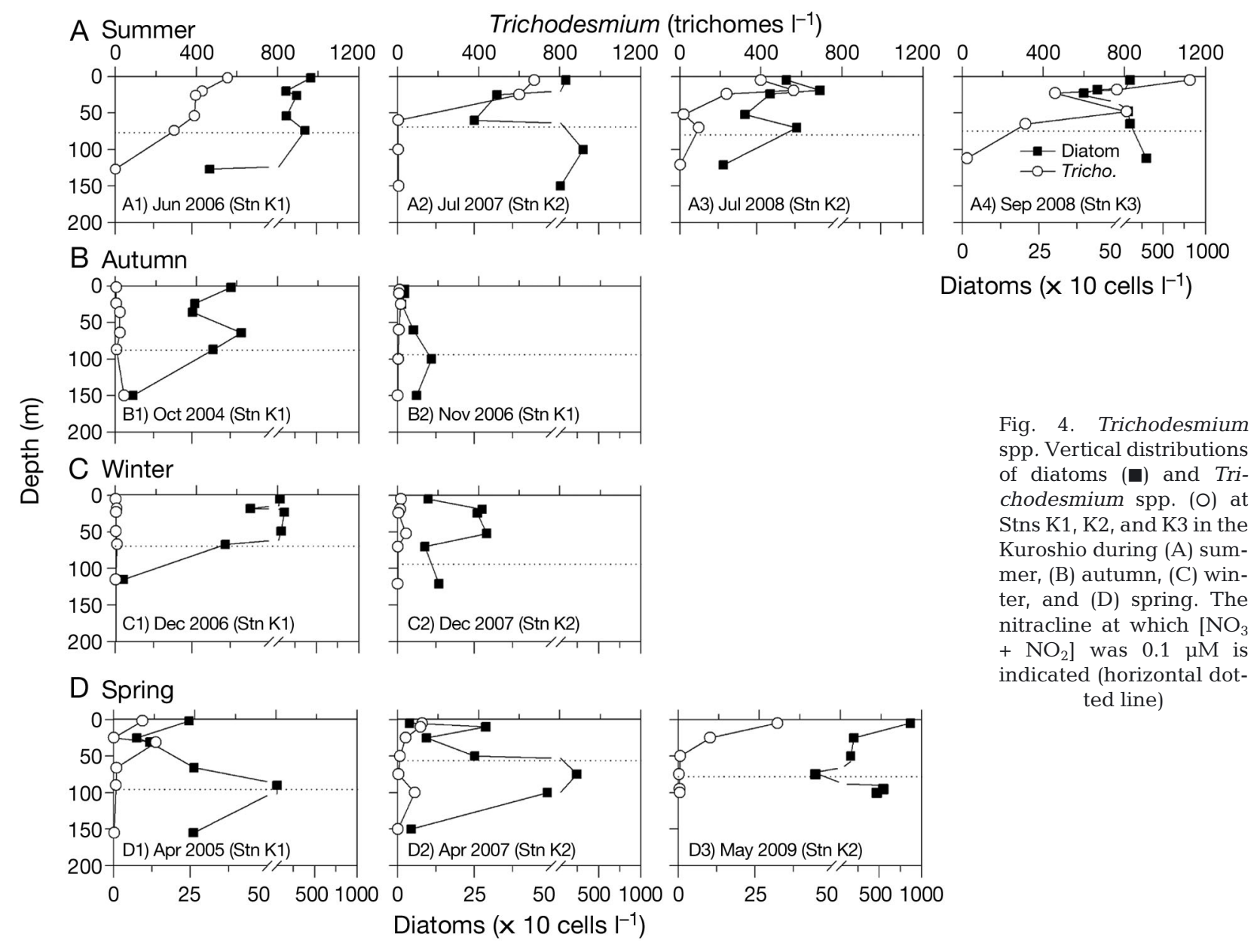

Table 6. Trichodesmium spp. Comparisons of ${ }^{15} \mathrm{~N}_{2}$ uptake rates in freshly collected colonies of Trichodesmium spp. from the Kuroshio Current and the South China Sea (SCS). Means $\pm \mathrm{SE}$

\begin{tabular}{|llccc|}
\hline Region & Season & Stn & Cruise & $\begin{array}{c}{ }^{15} \mathrm{~N}_{2} \text { uptake rate } \\
\left(\mathrm{nmol} \mathrm{N} \text { colony }{ }^{-1} \mathrm{~h}^{-1}\right)\end{array}$ \\
\hline Kuroshio & Summer & K1 & 1160 & 0.07 \\
& & K3 & 1316 & $0.18 \pm 0.02$ \\
& Autumn & K1 & 734 & $0.08 \pm 0.03$ \\
& Winter & K1 & 819 & $0.13 \pm 0.02$ \\
& Kpring & K1 & 852 & 0.03 \\
SCS & Skring & S & 717 & $0.11 \pm 0.01$ \\
& & & & 0.02 \\
\hline
\end{tabular}

\section{$\mathbf{N}_{2}$ fixation rates of Trichodesmium spp. in the field}

$\mathrm{N}_{2}$ assimilation rates of Trichodesmium spp. measured in the Kuroshio varied between 0.03 and $0.18 \mathrm{nmol} \mathrm{N}$ colony ${ }^{-1} \mathrm{~h}^{-1}$ (Table 6). The highest rate was observed in summer and the lowest in winter. The single measurement obtained in the SCS in spring was $0.02 \mathrm{nmol} \mathrm{N}$ colony $\mathrm{y}^{-1} \mathrm{~h}^{-1}$, which was lower than the Kuroshio rates.

\section{DISCUSSION}

The present study indicates clearly that Trichodesmium spp. and diatoms co-occurred in the upstream Kuroshio during the warm water season when Trichodesmium spp. flourished. While Trichodesmium spp. had the highest abundances near the surface, diatoms had high abundances near the surface Trichodesmium spp. maximum (Fig. 4A,D) and near the nitracline at the bottom of the euphotic layer. The surface diatom maximum disappeared when Trichodesmium spp. abundance decreased in the cold water season and re-emerged when the Trichodesmium spp. population resurged. Co-occurrence of diatoms and Trichodesmium spp. in surface water is a rather unusual phenomenon. It has been widely accepted that blooms of diatoms and Trichodesmium spp. tend to occur in different oceanic regimes. Diatoms grow well in turbulent waters with abundant nutrients and usually thrive in coastal or upwelling waters instead of open oceans, in temperate oceans instead of in subtropical or tropical oceans, and in winter instead of summer, but Tricho- 
A Summer Trichodesmium (trichomes $\mathrm{I}^{-1}$ )
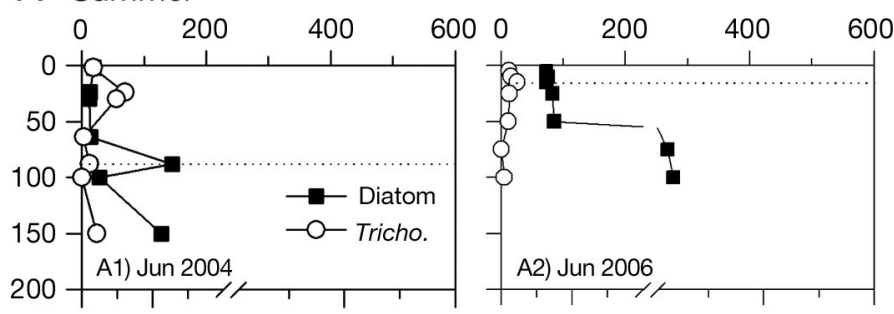

B Autumn
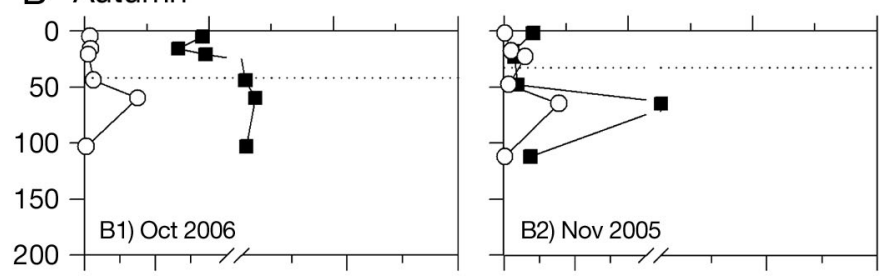

C Winter
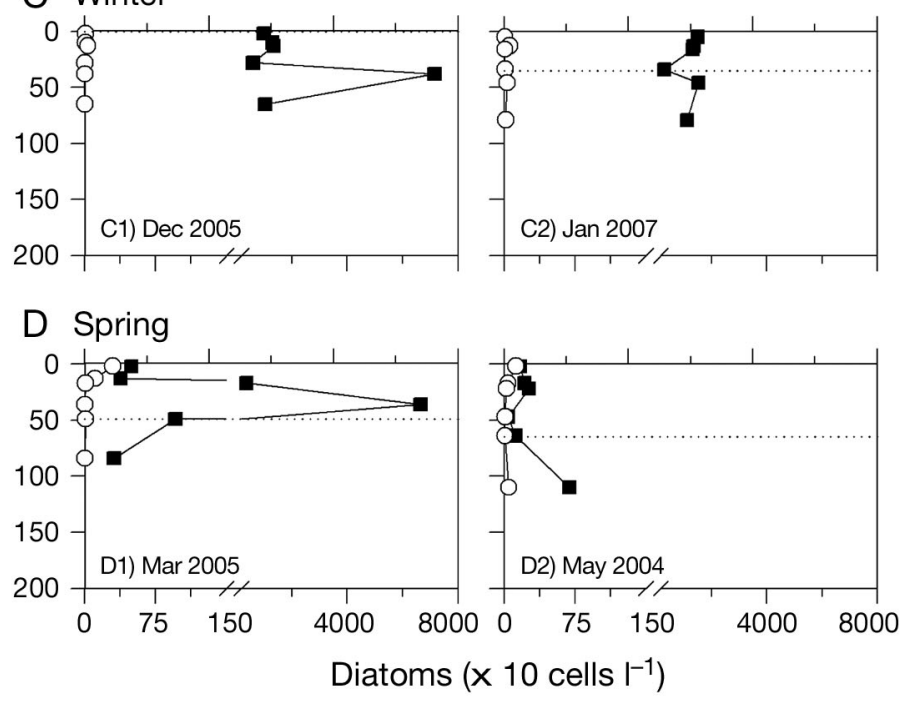

Fig. 5. Trichodesmium spp. Vertical distributions of diatoms (घ) and Trichodesmium spp. (O) at Stn S in the South China Sea during (A) summer, (B) autumn, (C) winter, and (D) spring. The nitracline at which $\left[\mathrm{NO}_{3}+\mathrm{NO}_{2}\right]$ was $0.1 \mu \mathrm{M}$ is indicated (horizontal dotted line)

desmium spp. flourishes in warm, calm, oligotrophic waters that are often depleted in $\mathrm{N}$.

An intuitive and direct explanation for the co-occurrence of diatoms and Trichodesmium spp. was that the flourishing Trichodesmium spp. provided the limiting nutrient(s) needed to support the growth of the diatoms in the nutrient-depleted oligotrophic surface waters. In both the Kuroshio and the SCS, N is the most likely nutrient limiting phytoplankton growth (Wu et al. 2003, Chen \& Chen 2006, Chen et al. 2008). The fixed $\mathrm{N}$ released by the thriving Trichodesmium could alleviate the deficiency, especially in the Kuroshio in summer (Table 6). The $\mathrm{N}_{2}$ fixation rates, which ranged between 0.07 and $0.18 \mathrm{nmol} \mathrm{N}$ colony ${ }^{-1} \mathrm{~h}^{-1}$, were comparable to the lower rates in summer in the tropical North Atlantic (0.003-0.08 and 0.01-0.23 nmol N colony ${ }^{-1} \mathrm{~h}^{-1}$; Capone et al. 2005, calculated by a conversion ratio of $4 \mathrm{~mol} \mathrm{C}_{2} \mathrm{H}_{4}$ formed to $1 \mathrm{~mol} \mathrm{~N}_{2}$ fixed), the Sargasso Sea (0.05 to $0.44 \mathrm{nmol} \mathrm{N}$ colony $^{-1} \mathrm{~h}^{-1}$; Orcutt et al. 2001), and the west Florida shelf in the Gulf of Mexico (0.17 to $0.77 \mathrm{nmol} \mathrm{N}$ colony $^{-1} \mathrm{~h}^{-1}$; Mulholland et al. 2006). Exudations of DON or ammonium from thriving Trichodesmium spp. could provide the $\mathrm{N}$ needed to support the growth of the phytoplankton nearby (Mulholland 2007). Planktonic diatoms are able to utilize various forms of DON (including urea, uric acid, alanine, glycine, serine, etc.) and DIN (ammonia, nitrate) to support their growth (Fisher \& Cowdell 1982). The results of our laboratory experiments confirmed this trophic linkage; the increased ${ }^{15} \mathrm{~N}$ signals in the diatom cells incubated with $T$. erythraeum (Table 2) indicated the presence of the newly fixed $\mathrm{N}$ from $T$. erythraeum.

In the present study, ${ }^{15} \mathrm{~N}$ enrichments in the nondiazotrophic phytoplankton after incubation with Trichodesmium erythraeum were significant in most tests even though some increments were small, such as for Thalassiosira weissflogii in Expt A. The small increments of ${ }^{15} \mathrm{~N}$ values after the co-incubation could be due to low availability of fixed ${ }^{15} \mathrm{~N}$ in the medium. Mulholland et al. (2004) found that the released fixed ${ }^{15} \mathrm{~N}$ did not accumulate in the growth media because it was rapidly taken up by Trichodesmium spp. In addition, several species of non-diazotrophic phytoplankton were incubated together with $T$. erythraeum in our study. Because the same $\mathrm{N}$ pool was shared by the phytoplankton, each species had access to only a fraction of the $\mathrm{N}$ pool, thus leading to small increments in ${ }^{15} \mathrm{~N}$ values. The among-species and between-experiment variability of the ${ }^{15} \mathrm{~N}$ enrichments could be attributed to the differences in physiological status of the test phytoplankton during the incubation experiments at least in part. For example, before and during the coincubations, all stock and experimental cultures were placed in a same incubator at $26^{\circ} \mathrm{C}$, which may not have been optimal for growth for each species of the test phytoplankton.

The relatively small increments of ${ }^{15} \mathrm{~N}$ values in diatoms from the co-incubations did not necessarily mean that the transfers of fixed $\mathrm{N}$ from Trichodesmium erythraeum to diatoms had similarly low rates. In the field, in addition to direct release of fixed N, cell lysis and viral infection of Trichodesmium spp. and the presence of grazers and associated sloppy feeding are important mechanisms for the release of available $\mathrm{N}$ from Trichodesmium spp. to the co-occurring phytoplankton. Mulholland et al. (2004) found that the rates of ${ }^{15} \mathrm{NH}_{4}{ }^{+}$and $\mathrm{DO}^{15} \mathrm{~N}$ production from newly fixed ${ }^{15} \mathrm{~N}_{2}$ 
by Trichodesmium spp. in the culture studies were lower than those measured in the field studies. They attributed these low rates to the absence of grazers in the cultures and to the presence of large intracellular pools of $\mathrm{NH}_{4}^{+}$and DON in cultured Trichodesmium spp. The co-occurrence of enhanced diatoms and Trichodesmium spp. biomass in the Kuroshio could result from these other mechanisms, in addition to direct release of $\mathrm{N}$ fixed by Trichodesmium spp.

A sufficient supply of silicon $(\mathrm{Si})$ relative to $\mathrm{N}$ may have supported the co-occurrence of Trichodesmium spp. and diatoms. Surface ratios of $\mathrm{SiO}_{2}: \mathrm{N}+\mathrm{N}$ in the Kuroshio (57) and (106) were both much greater than the Brzezinski's (1985) Si:N ratio of 1.12, which was derived from the study of 27 diatom species, and indicates sufficient silicate for diatom growth. The $\mathrm{Si}$ excess indicated that diatom growth in both regions was more likely limited by $\mathrm{N}$ than by $\mathrm{Si}$. In $\mathrm{N}$-limited ocean regions, any input of $\mathrm{N}$ would enhance phytoplankton growth. In the SCS during the warm water season, diatom biomass had only 1 maximum near the depth of the nitracline, where deep advection was the probable $\mathrm{N}$ source. This was especially true in winter when mixing was strong and $\mathrm{D}_{\mathrm{ni}}$ was shallow (Table 3 ). The significant relationship in seasonal dynamics between diatom population and nitracline depth in the SCS (Fig. 3D) supports this conclusion. In winter when the diatom population reached its maximum, silicate abundance decreased to its annual minimum, despite that the surface was replenished with $\mathrm{N}+\mathrm{N}$ and SRP from deep waters (Table 3 ). A maximum of diatoms in the lower euphotic layer near the nutricline is common in oligotrophic oceanic waters. Some diatom species adapt to low light conditions (Goldman 1993) and even generate substantial production at depth (Kemp et al. 2000). Diatoms have no direct light requirement for $\mathrm{Si}$ uptake as long as they are growing actively. Si uptake could continue through the night, sometimes at rates that are undiminished from daytime rates (Brzezinski \& Nelson 1989, Nelson \& Brzezinski 1997, Brzezinski et al. 1998).

Next to N, P and Fe are the 2 elements often considered most limiting to growth of oceanic phytoplankton. The co-occurrences of diatoms and Trichodesmium spp. were observed only during summer in surface Kuroshio but not in the SCS, but $\mathrm{P}$ and Fe cannot explain this difference. Surface P was relatively abundant in both SCS and Kuroshio. Surface N+N:SRP ratios $(<2.6)$ were much smaller than the Redfield N:P ratio of 16 , indicating $\mathrm{N}$ rather than $\mathrm{P}$ limitation (Table 3). Summertime surface SRP concentrations did not differ significantly between the 2 regions (Table 3 ). $\mathrm{P}$ enrichment in the SCS did not enhance phytoplankton growth, suggesting that P did not limit phytoplankton growth there (Wu et al. 2003). Thus, P limitation is unlikely to have caused the lack of co-occurrence of diatoms and Trichodesmium spp. in the SCS.

Fe status was not investigated in the present study. The abundance of Fe or dissolved Fe in this part of the Kuroshio has not been reported; however, dissolved Fe concentrations were low $(0.2$ to $0.3 \mathrm{nM})$ in the surface water of the SCS and the concentration was independent of dust deposition in this dust-rich region (Wu et al. 2003). Wu et al. (2003) hypothesized that the low dissolved $\mathrm{Fe}$ concentrations might result from low Fe solubility due to a lack of Fe-binding organic ligands in the surface water. Therefore, a shortage of dissolved Fe might result in low population densities of Trichodesmium spp. in the SCS. Non-diazotrophic organisms such as diatoms, on the other hand, are not necessarily Fe-limited even when Trichodesmium spp. become Fe-limited. The Fe requirements of $\mathrm{N}_{2}$-fixers are 10 times higher than those of non-diazotrophic phytoplankton that use fixed $\mathrm{N}$ exclusively (Paerl et al. 1994, Sañudo-Wilhelmy et al. 2001). Nutrient enrichment studies conducted in both summer and winter in the SCS (Chen \& Chen 2006) revealed that only $\mathrm{N}$ additions increased phytoplankton growth when $\mathrm{N}, \mathrm{P}$, and Fe were tested. Therefore, we conclude that $\mathrm{P}$ and Fe were unlikely to explain the absence of surface maxima in diatom vertical distributions in the SCS. The sparse distribution of Trichodesmium spp. that could release newly fixed $\mathrm{N}$ to support diatom growth would be a more probable cause. On the other hand, although $\mathrm{P}$ (and possibly $\mathrm{Fe}$ ) is not a limiting nutrient in the Kuroshio, its sufficiency is likely to vary depending on the success of diatoms. If diatoms bloom as a result of the fixed $\mathrm{N}$ fluxes, intense competition for $\mathrm{P}$ (or $\mathrm{Fe}$ ) among phytoplankton would eventually result.

Although the laboratory experiments focused on $\mathrm{N}$ fluxes, we also have some results on $\mathrm{C}$ assimilation. The diatoms assimilated less $\mathrm{C}$ when incubated with Trichodesmium erythraeum than without (Table 2). During the incubations, the diatoms in the membrane tubes were shaded by the surrounding $T$. erythraeum outside the tubes, which may have led to reduced $\mathrm{C}$ assimilation. Similar shading effects may occur in the field; however, in the Kuroshio where solar irradiation is strong (summertime PAR values at noon often exceed $2000 \mu \mathrm{mol} \mathrm{m} \mathrm{m}^{-2} \mathrm{~s}^{-1}$ ) and $\mathrm{N}$ is limiting, the positive effects from nutrient enrichment could be greater than the negative effect from shading, if it exists. The co-occurrence of diatoms and Trichodesmium spp. supported this assertion.

Non-diazotrophic phytoplankton utilizing the extracellular products of cyanobacteria in nature has seldom been reported (Garcia et al. 2007). In the North Pacific Central Gyre, Venrick (1974) found that increased chlorophyll concentrations in summer were associated with high abundances of Richelia intracellularis. She 
postulated that the general increase in phytoplankton was a response to an initial increase in $R$. intracellularis abundance and a consequent increase in inorganic $\mathrm{N}$ availability. The only report for diatoms showed high diatom abundance during and immediately after a Trichodesmium spp. bloom in the near-shore waters of Goa, western India (Devassy et al. 1978). In that study, Nitzschia closterium was the predominant diatom during the bloom and Asterionella japonica became abundant immediately after Trichodesmium spp. disappeared. Our results are the first systematic observations of the co-occurrence of diatoms and Trichodesmium spp. in the open ocean. Relative to diatoms, picophytoplankton, because of their large surface area to volume ratios, usually have higher affinities for N. They are good candidates to scavenge fixed $\mathrm{N}$ excreted by Trichodesmium spp., although their biomasses were not quantified in the present field study. Both Prochlorococcus marinus and Synechococcus sp. had higher ${ }^{15} \mathrm{~N}$ values when they were incubated with $T$. erythraeum than without (Table 2). Growth of Synechococcus spp. in the Baltic Sea was attributed to $N$ released during the blooms of the diazotrophic cyanobacteria Nodularia spp. and Aphanizomenon spp. (Ohlendieck et al. 2000). Likewise, ${ }^{15} \mathrm{~N}$ accumulated in the $<3 \mu \mathrm{m}$ size fraction in southwestern Pacific oceanic waters around New Caledonia due to picoplanktonic uptake of the newly released fixed $\mathrm{N}$ from larger diazotrophs such as Trichodesmium spp. or diazotrophic unicellular nanoplankton (Garcia et al. 2007). Further studies to examine the responses of picophytoplankton to the ubiquitous Trichodesmium in the Kuroshio are needed to elucidate the different interactions among various phytoplankton assemblages.

The rate of fixed $\mathrm{N}$ release by Trichodesmium erythraeum in the growth medium was not calculated in the present study because it was designed only to reveal whether ${ }^{15} \mathrm{NH}_{4}{ }^{+}$or $\mathrm{DO}^{15} \mathrm{~N}$ released by $T$. erythraeum was taken up by the co-incubating non-diazotrophic phytoplankton. Mulholland et al. (2004) measured the rates of ${ }^{15} \mathrm{NH}_{4}{ }^{+}\left(5.3\right.$ to $\left.72.9 \mathrm{nmol} \mathrm{N} \mathrm{l}^{-1} \mathrm{~h}^{-1}\right)$

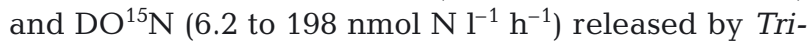
chodesmium spp. to the medium. They found that the released ${ }^{15} \mathrm{~N}$ did not accumulate in the media because it was simultaneously taken up by Trichodesmium spp. In order to ensure that the fixed ${ }^{15} \mathrm{~N}$ could be transferred to the co-incubated phytoplankton and detected experimentally after the relatively short incubation time, the $T$. erythraeum biomass $\left(9.8 \times 10^{5}\right.$ trichomes $\mathrm{l}^{-1}$ ) used in our experiment was 2 to 3 orders higher than in the ocean. Also, the concentration of ${ }^{15} \mathrm{~N}_{2}$ tracer added in the incubations was 3 times the concentration commonly used in $\mathrm{N}_{2}$-fixation studies. The experimental design, although necessary to detect the transfer of fixed $\mathrm{N}$ to the non-diazotrophic phytoplankton, con- strained estimation of the uptake rates of ${ }^{15} \mathrm{NH}_{4}{ }^{+}$or $\mathrm{DO}^{15} \mathrm{~N}$ by the non-diazotrophic phytoplankton. If the rates had been quantified, they would not have represented realistic values in the oceans.

Enhancement of diatom abundance from co-occurrence with Trichodesmium spp. might increase export of surface $\mathrm{C}$ and $\mathrm{N}$ to depth. Sinking of ungrazed large cells, such as diatoms, may determine the downward flux of particulate organic C (Boyd \& Newton 1999). Diatoms have high silica content and often produce biological glues that may promote aggregation and hence facilitate sinking rates (Passow et al. 1994). Picophytoplankton and Trichodesmium spp. are the predominant primary producers in surface water of oligotrophic tropical oceans. While picophytoplankton seldom sink due to small cell sizes (Takahashi \& Bienfang 1983), sinking of Trichodesmium spp. is unlikely because of cell buoyancy (Walsby 1992). Both of their trophic contributions are primarily nutrient recycling in the surface ocean through cell lyses, extracellular release, or zooplankton grazing. In contrast, diatoms as cells or in fecal pellets of zooplankton are more likely to sink. Diatoms, unlike Trichodesmium spp. which have toxins as grazing deterrents, could be more palatable than Trichodesmium spp. to most predominant calanoid or cyclopoid copepods in the water column (Hawser et al. 1992). The trophic transfer from Trichodesmium spp. to co-occurring diatoms thus provides a potentially more efficient pathway for the newly fixed $\mathrm{N}$ to be exported to depth. Data on isotopically light sediment trap materials collected in the Indian Ocean (Capone et al. 1998) and at the Atlantic and Pacific time series sites (Karl et al. 1997, 2002, Knapp et al. 2005) where Trichodesmium spp. was blooming suggested that at least some $\mathrm{N}$ derived from recently fixed $\mathrm{N}_{2}$ left the euphotic zone. Further studies are needed to determine whether actual downward fluxes would couple with the increase of diatoms in the phytoplankton community.

Acknowledgments. We thank Y. H. Lin, C. C. Huang, Y. J. Liao, H. Sen, and B. R. Huang for their assistance in sample collection and analyses, the captains and crews of the RVs 'Ocean Researcher' I and III for their cooperation, and Sea Pen Scientific Writing for editing services. We are grateful to 3 anonymous reviewers for their valuable comments and suggestions. This research was supported in part by the National Science Council through grants NSC 95-2611M110-002, 96-2628-M110-005, 97-2628-M110-002, and 972611-M110-006-MY2.

\section{LITERATURE CITED}

Boyd PW, Newton PP (1999) Does planktonic community structure determine downward particulate organic carbon flux in different oceanic provinces? Deep-Sea Res I 46: $63-91$ 
Brzezinski MA (1985) The Si:C:N ratio of marine diatoms: interspecific variability and the effect of some environmental variables. J Phycol 21:347-357

Brzezinski MA, Nelson DM (1989) Seasonal changes in the silicon cycle within a Gulf Stream warm-core ring. DeepSea Res A 36:1009-1030

Brzezinski MA, Villareal TA, Lipschultz F (1998) Silica production and the contribution of diatoms to new and primary production in the Central North Pacific. Mar Ecol Prog Ser 167:89-104

Capone DG (2001) Marine nitrogen fixation: What's the fuss? Curr Opin Microbiol 4:341-348

Capone DG, Ferrier MD, Carpenter EJ (1994) Amino acid cycling in colonies of the planktonic marine cyanobacterium, Trichodesmium thiebautii. Appl Environ Microbiol 60:3989-3995

Capone DG, Zehr JP, Paerl HW, Bergman B, Carpenter EJ (1997) Trichodesmium, a globally significant marine cyanobacterium. Science 276:1221-1229

Capone DG, Subramaniam A, Montoya JP, Voss M, Humborg C, Johansen AM, Siefert RL, Carpenter EJ (1998) An extensive bloom of the $\mathrm{N}_{2}$-fixing cyanobacterium Trichodesmium erythraeum in the central Arabian Sea. Mar Ecol Prog Ser 172:281-292

> Capone DG, Burns JA, Montoya JP, Subramaniam A and others (2005) Nitrogen fixation by Trichodesmium spp.: an important source of new nitrogen to the tropical and subtropical North Atlantic Ocean. Global Biogeochem Cycles 19:GB2024

- Carpenter EJ, Romans K (1991) Major role of the cyanobacterium Trichodesmium in nutrient cycling in the North Atlantic Ocean. Science 254:1356-1358

Chen YLL, Chen HY (2006) Seasonal dynamics of primary and new production in the northern South China Sea: the significance of river discharge and nutrient advection. Deep-Sea Res I 53:971-986

> Chen YLL, Chen HY, Lin YH (2003) Distribution and downward flux of Trichodesmium in the South China Sea as influenced by the transport from the Kuroshio Current. Mar Ecol Prog Ser 259:47-57

> Chen YLL, Chen HY, Lin II, Lee MA, Chang J (2007) Effects of cold eddy to phytoplankton production and assemblages in Luzon Strait bordering the South China Sea. J Oceanogr 63:671-683

Chen YLL, Chen HY, Tuo S, Ohki K (2008) Seasonal dynamics of new production from Trichodesmium $\mathrm{N}_{2}$ fixation and nitrate uptake in the upstream Kuroshio and South China Sea basin. Limnol Oceanogr 53:1705-1721

Cupp EE (1977) Marine plankton diatoms of the west coast of North America. Otto Koeltz Science Publishers, Koenigstein

Devassy VP, Bhattathiri PMA, Qasim SZ (1978) Trichodesmium phenomenon. Indian J Mar Sci 7:168-186

Draper NR, Smith H (1981) Applied regression analysis. Wiley, New York, NY

- Fisher NS, Cowdell RA (1982) Growth of marine planktonic diatoms on inorganic and organic nitrogen. Mar Biol 72: $147-155$

Garcia N, Raimbault P, Sandroni V (2007) Seasonal nitrogen fixation and primary production in the southwest Pacific: nanoplankton diazotrophy and transfer of nitrogen to picoplankton organisms. Mar Ecol Prog Ser 343:25-33

Garside C (1982) A chemiluminescent technique for the determination of nanomolar concentrations of nitrate and nitrite in seawater. Mar Chem 11:159-167

Glibert PM, Bronk DA (1994) Release of dissolved organic nitrogen by marine diazotrophic cynobacteria, Trichodesmium spp. Appl Environ Microbiol 60:3996-4000
Goldman JC (1993) Potential role of large oceanic diatoms in new primary production. Deep-Sea Res I 40:159-168

Hawser SP, O'Neil JM, Roman MR, Codd GA (1992) Toxicity of blooms of the cyanobacterium Trichodesmium to zooplankton. J Appl Phycol 4:79-86

Karl DM, Letelier R, Hebel DV, Bird DF, Winn CD (1992) Trichodesmium blooms and new nitrogen in the North Pacific Gyre. In: Carpenter EJ, Capone DG, Rueter JG (eds) Marine pelagic cyanobacteria: Trichodesmium and other diazotrophs. Kluwer Academic Publishers, Amsterdam, p 219-237

Karl DM, Letelier R, Tupas L, Dore J, Christian J, Hebel D (1997) The role of nitrogen fixation in biogeochemical cycling in the subtropical North Pacific. Nature 388: 533-538

Karl DM, Michaels A, Bergman B, Capone D and others (2002) Dinitrogen fixation in the world's oceans. Biogeochemistry 57/58:47-98

Kemp AES, Pike J, Pearce RB, Lange CB (2000) The 'fall dump' - a new perspective on the role of a 'shade flora' in the annual cycle of diatom production and export flux. Deep-Sea Res II 47:2129-2154

> Knapp AN, Sigman DM, Lipschultz F (2005) N isotopic composition of dissolved organic nitrogen and nitrate at the Bermuda Atlantic Time-series Study site. Global Biogeochem Cycles 19:GB1018

> Le Borgne R, Barber RT, Delcroix T, Inoue HY, Mackey DJ, Rodier M (2002) Pacific warm pool and divergence: temporal and zonal variations on the equator and their effects on the biological pump. Deep-Sea Res II 49: 2471-2512

> Lenes JM, Darrow BP, Cattrall C, Heil CA, Callahan M, Vargo GA, Byrne GH (2001) Iron fertilization and the Trichodesmium response on the West Florida shelf. Limnol Oceanogr 46:1261-1277

> Liang WD, Tang TY, Yang YJ, Ko MT, Chung WS (2003) Upper-ocean currents around Taiwan. Deep-Sea Res II 50: 1085-1105

> Montoya JP, Voß M, Kähler P, Capone DG (1996) A simple, high precision tracer assay for dinitrogen fixation. Appl Environ Microbiol 62:986-993

Montoya JP, Holl CM, Zehr JP, Hansen A, Villareal TA, Capone DG (2004) High rates of $\mathrm{N}_{2}$ fixation by unicellular diazotrophs in the oligotrophic Pacific Ocean. Nature 430: 1027-1031

> Mulholland MR (2007) The fate of nitrogen fixed by diazotrophs in the ocean. Biogeosciences 4:37-51

> Mulholland MR, Capone DG (2001) The stochiometry of N and $\mathrm{C}$ utilization in cultured populations of Trichodesmium IMS101. Limnol Oceanogr 46:436-443

Mulholland MR, Bronk DA, Capone DG (2004) $\mathrm{N}_{2}$ fixation and regeneration of $\mathrm{NH}_{4}{ }^{+}$and dissolved organic $\mathrm{N}$ by Trichodesmium IMS101. Aquat Microb Ecol 37:85-94

> Mulholland MR, Bernhardt PW, Heil CA, Bronk DA, O'Neil JM (2006) Nitrogen fixation and release of fixed nitrogen by Trichodesmium spp. in the Gulf of Mexico. Limnol Oceanogr 51:1762-1776

Nelson DM, Brzezinski MA (1997) Diatom growth and productivity in an oligotrophic mid-ocean gyre: a 3-yr record from the Sargasso Sea near Bermuda. Limnol Oceanogr 42:473-486

Ohlendieck U, Stuhr A, Siegmund H (2000) Nitrogen fixation by diazotrophic cyanobacteria in the Baltic Sea and transfer of the newly fixed nitrogen to picoplankton organisms. J Mar Syst 25:213-219

> Orcutt KM, Lipschultz F, Gundersen K, Arimoto R, Michaels AF, Knap AH, Gallon JR (2001) A seasonal study of the 
significance of $\mathrm{N}_{2}$ fixation by Trichodesmium spp. at the Bermuda Atlantic Time-series Study (BATS) site. DeepSea Res II 48:1583-1608

Paerl HW, Prufert-Bebout LE, Guo C (1994) Iron-stimulated $\mathrm{N}_{2}$ fixation and growth in natural and cultured populations of the planktonic marine cyanobacteria Trichodesmium spp. Appl Environ Microbiol 60:1044-1047

Pai SC, Riley JP (1994) Determination of nitrate in presence of nitrite in natural water by flow injection analysis with a non-quantitative on-line cadmium reductor. Int J Environ Anal Chem 57:263-277

Pai SC, Yang CC, Riley JP (1990) Effects of acidity and molybdate concentration on the kinetics of the formation of the phosphoantimonylmolybdenum blue complex. Anal Chim Acta 229:115-120

Passow U, Alldredge AL, Logan BE (1994) The role of particulate carbohydrate exudates in the flocculation of diatom blooms. Deep-Sea Res I 41:335-357

Sañudo-Wilhelmy SA, Kustka AB, Gobler CJ, Hutchins DA and others (2001) Phosphorus limitation of nitrogen fixa-

Editorial responsibility: Graham Savidge,

Portaferry, UK tion by Trichodesmium in the central Atlantic Ocean. Nature 411:66-69

Takahashi M, Bienfang PK (1983) Size structure of phytoplankton biomass and photosynthesis in subtropical Hawaiian waters. Mar Biol 76:203-211

Thomson-Bulldis A, Karl D (1998) Application of a novel method for phosphorus determinations in the oligotrophic North Pacific Ocean. Limnol Oceanogr 43:1565-1577

Venrick EL (1974) The distribution and significance of Richelia intracellularis Schmidt in the North Pacific Central Gyre. Limnol Oceanogr 19:437-445

Walsby AE (1992) The gas vesicles and buoyancy of Trichodesmium. In: Carpenter EJ, Capone DG, Rueter JG (eds) Marine pelagic cyanobacteria: Trichodesmium and other diazotrophs. Kluwer Academic Publishers, Amsterdam, p 141-161

Wu J, Chung SW, Wen LS, Liu KK, Chen YLL, Chen HY, Karl DM (2003) Dissolved inorganic phosphorus, dissolved iron, and Trichodesmium in the oligotrophic South China Sea. Global Biogeochem Cycles 17:1008

Submitted: May 25, 2010; Accepted: October 29, 2010 Proofs received from author(s): January 6, 2011 